\title{
Effects of Corporate Governance on the Performance of Nepalese Firms
}

\author{
Prem Prasad Silwal*
}

\begin{abstract}
The paper examines the effect of corporate governance on the performance of Nepalese firms. Return on assets, return on equity and Tobin's $Q$ are the dependent variable for firm performance and firm size, leverage, board size, age of the firm, and audit committee are the explanatory variables. Data are collected from annual report of 18 non financial firms listed in NEPSE from 2010 to 2015. The multiple regression models were estimated to test the effect of explanatory variables on firm performance. The result reveals that corporate governance has significant impact on firms' performance based on return on assets. Board size, and leverage have negative and significant effect on firm performance however age of the firm and audit committee have positive effect on firm performance based on return on equity. While regressing firm performance based on Tobin's $Q$, board size and audit committee are the major factors in determining the firm performance.
\end{abstract}

Key words: Board size, firm performance, corporate governance, audit committee, return on equity

*Mr. Silwal, M.Phil. Finance, is teaching faculty at Nepal College of Management, Kathmandu University. Email: silwal.prem328@gmail.com. Currently Ph.D. Scholar at Tribhuvan University. 


\section{Introduction}

The concept of corporate governance has been increasing public interest in recent years due to its plausible importance on the economic health of corporation in general. While financial crisis at culmination, regulators, government and academicians tend to focus on the corporate governance more enthusiastically in order to enhance investors' confidence that would attract more employment of fund in business. Evidence suggests that firms in growing economies are low priced in financial markets because of weak governance (LaPorta, Lopez-de-Silanes, Shleifer, and Visny, 2000). As such, improvements in corporate governance can enhance investor confidence increase these firms' access to capital market (Rajagopalan and Zhang, 2009). Nowadays, it is not sufficient for the company merely be profitable, it also needs to show good corporate citizenship through environmental awareness, ethical behavior and well corporate governance practices.

Generally, corporate governance in non financial sectors require judicious and prudent use of resources of the firm to increase corporate value, increase employee morale, maintenance of market discipline, and stabilize the organization in its end. Corporate governance, thus, rightly, defined as the ways in which suppliers of finance and goods assure themselves that they will receive a fair return on their investment (Shleifer and Vishny, 1997). If this situation does not exist, outside investor will not be motivated to buy the equity of that firm. This would thus firm tend to force to employ internal resources for the firms' profitable investment opportunities. If so then efficiency of the overall performance would likely to suffer and employees and consumers tend to move other firms in the industry.

Jensen and Meckling (1976), Fama and Jensen (1983) revealed that inducement has been given to the managers to confiscate the assets of the firm by endorsing profitable projects, but this is much beneficial to the executives rather than maximizing the value of the firm. Brown and Caylor (2004) asserted that, regulators and government advocates argue that in most of the cases market value becomes overpriced due to poor governance and if this is right the market value of the well governed firm should be relatively undervalued than poor governed firm.

Empirical evidences show that greater shareholders rights create higher growth rates, higher profitability and lower cost of capital. Shareholders rights have often been measured after following certain rules and regulation adopted by concern authority (Gompers, Ishii and Metrick, 2003, Bebchuk, Cohen and Ferrell, 2009, Bebchuk, 2006).

Another line of research in the area of corporate governance has been the investigation of several components of board governance, such as board size, composition of board, frequency of board meeting and the audit committee, as they relate to financial efficiency. 
There are a number of regulations in place that governs the activities of companies in Nepal and some of these are: Securities and Exchange act 1983 and security rules 1993 are the basic law which provides protection for investors, regulate markets, dealings and related matters, and conserving from frauds.

Nepal Rastra Bank (2010), the central bank of Nepal issued regulation to the financial institution to maintain certain standard for corporate governance; hence people's trust has been increased. In terms of banking Act 2014, the Nepal Rastra Bank, now has a strong legal basis for supervising banking institutions. It has been noted that licensing function has been stopped; merging process has been initiated as each and every bank needs to increase its capital to Rs 8,000 million. The bank should increase this amount either by issuing right share or by merging with another financial institution. Additionally, Banking Act regulates financial institutions to disclose their financial statement on each quarter for the information of the public. This has helped significantly in instilling discipline and good corporate governance among the financial institutions. Similarly, company Act 2006 establishes the rules for the governance and regulation of companies based on this act.

Company Act (2006, clause 164) A company listed in Nepal Stock Exchange with a paid up capital of rupees thirty million or more or a company which is fully or partly owned by the government of Nepal should form an audit committee under the chairmanship of a director who is not involved in daily work of the company consisting of at least three members. It ensures that companies running under this act bounded to make their accounting transparent. Company should prepare bylaws for audit committee. This committee should review the firm's financial position, internal controls, financial activities performed by those companies and information revealed by internal auditor.

OECD (2004) establishes certain principles of corporate governance, which have adopted by member countries. As per OECD, corporate governance involves a set of relationship between company's management, its board, its shareholders and other stakeholders.

The main purpose of this study is to find out the impact of corporate governance on firm performance in Nepalese firm with the following specific objectives:

- To measure the corporate governance practices

- To examine the effect of corporate governance and firm performance

- To find out the major indicators of corporate governance

Several such type of research has been conducted in western countries and produced the evidence in corporate governance and firm performance (Fama and Jensen, 1983, Shleifer and Vishny, 1997, Hillaman and Dalziell, 2003, Nicholson and Kiel, 2007). However, to my knowledge this investigation has not so far been sufficiently conducted at Nepalese firms, 
hence researcher would like to through some light in corporate governance and firm performance in Nepalese firms listed in NEPSE.

The paper is organized into five sections. Section II of this study deals with the review of literature, and theoretical framework of this study while section III presents the research methodology. Overall analysis has been presented in section IV and summary and conclusion are presented in section five.

\section{Review of Literature}

This section deals with the overview of previous studies to identify the recent body of knowledge that affect corporate performance. In corporate finance, it is important to see the impact of firm specific variables on firm performance because return on assets, return on equity, market value of equity are key ratios through which firm efficiency can be measured. The paper is followed by a review of past literature examining the relationship of corporate governance and firm performance. Based on these established foundation on the subject matter hypothesis is presented along with theoretical framework.

\subsection{Corporate governance variables}

The study of corporate governance does influence firm performance is widely spread in developed countries, however the outcomes are contrary. For instance, Larcker and Tuna (2007) ascertain that corporate governance and firm performance fail to produce consistent return whereas Fallatah and Dickins (2012) reveal that corporate governance and firm performance measured by return on assets is uncorrelated but firm performance measured by Tobin's $Q$ is positively associated.

The variables include board size, age of the firm, leverage, proportion of non executive members which are the major corporate governance variables.

\subsubsection{Board size}

In order to see the association between board size and firm performance, there are two school of thoughts. The argument of first school of thought is a smaller the size of board the higher the success of the firm (Lipton and Lorsch, 1992, Jensen, 1993). The second school of thought reveals that larger the size of board, the higher the firm performance (Klein, 1998, Coles, 2008). Moreover, large board size has more access to the market and gather more information results that a large board size appears to be better for firm performance (Dalton et al.,1999). These studies assert that a large board will support and advise management more effectively due to complex and competitive business environment (Klein, 1998).

$\mathrm{H} 1$ : There is a positive association between board size and firm performance.

\subsubsection{Age}


The age of Corporate firm has been used by numerous studies in terms of number of years a firm has been established. (Berger and Udell, 1998; Boone et al., 2007). They asserted that firm age is a relevant indicator of expected growth opportunities. For instance, Claessens et al., (2002) confirmed that matured and larger firms have more liquid trading, better disclosure, well diversified, managing portfolio in reducing risk but less growth opportunity. However, young and smaller firms have better growth opportunity but greater exposure to adverse market conditions. Evans (1987) concluded that older and larger firms have greater skill and experience, but less dynamic and flexible with market environment. Borghesi et al., (2007) evidenced that older firms are unable to make quick response to grab market change. In a same line, Lipczinsky and Wilson (2001) opined that young firms are expected to earn less profit that aged firms due to less experienced in the market, actually, they are trying to recover their cost.

H3: There is a positive association between age and firm performance.

\subsubsection{Leverage}

If firm could not supply the fund internally then it should go into the market and raise the capital by issuing long term securities. The long term securities are either equity capital or long term debt. In this regard, firm may raise its financing requirement from long term debt to uplift the firm's business, is leverage. Weill (2003) revealed that leverage is one of the proxies of corporate performance. The study shows that there is negative association between leverage and corporate performance in Italy whereas positive association in France and Germany. Similarly, Majumdar and Chhibber (1999) tested the relationship between leverage and corporate performance in Indian firms results that there is negative and significant relationship between leverage and corporate performance.

$\mathrm{H} 4$ : There is a negative association between leverage and firm performance

\subsubsection{Audit committee}

Goldman and Barlev (1974) reveal on the transparency that audit committee maintains in the business. According to them, audit committee could observe the financial reporting process; select the auditors with terms and conditions and delegation of power of attorney. In Nepal, company registration office laid the foundation of appointing audit committee for the firm which has more than Rs 30 million investments. An audit committee is entitled to ensure that a corporate firm has sufficient internal controls, effective accounting policies, and independent accounting policies to avoid fraud, embezzlement, enhance morality, and produce timely financial report. Based on this, the study develops the following hypothesis:

H5: There is a positive association between audit committee and firm performance.

\subsubsection{Firm size}


There are several evidences that firm size plays crucial role in corporate governance and firm performance. Total assets are used to analyze a firm's size. The larger the firm is the higher the managing efficiency. Ramzan (2013) reveals that firm size has positive significant relationship with the return on assets (firm performance). Thus, it is hypothesized that larger the firm better the corporate performance.

H6: There is a positive association between firm size and firm performance.

\subsection{Corporate governance and firm performance}

Corporate governance refers to the process and structures employed to direct and manage the business with an aim to increasing the shareholders value. There are various measures of firm performance, this study employs pre-established approached and used three financial measures of firm performance, return on equity, return on assets and Tobin's Q. Financial measures such as ROE, ROA are better measure of firm performance (Rehman and Haniffa, 2006 and Awan, 2012,). Financial measures of firm performance fit into accounting based measures.

\subsection{Theoretical framework}

Based on the previous overview of the study and hypothesis, following conceptual framework has been formed:

Theoretical framework

\begin{tabular}{|l|l|}
\hline Governance issues \\
Leverage \\
Age \\
Audit committee
\end{tabular}

Figure 2.1

Figure 2.1 shows the conceptual framework where corporate governance issues are indicated by firm size, board size, debt ratio, age of the firm and audit committee. The firms' performance, the dependent variable, is measured by return on assets, return on equity and Tobin's $Q$. 


\section{Methodological aspect}

This study is based on secondary data. In order to achieve the objective of this study, there are 33 non financial firms listed in NEPSE which are considered as population of the study and 18 non financial firms are selected as sample of the study. The required data are collected from annual report of respective firms and NEPSE data base. The pooled cross sectional data analysis has been carried out in this study. The research design employed in this study is descriptive and causal comparative as it deals with relationship with corporate governance variables with firm performance. Moreover, the study examines the effect of board size, leverage, age, audit committee, firm size with return and Tobin's $Q$. The data were gathered from 2009/10 to 2014/15 as presented in Appendix 1.

\section{Model specification}

As specified in the above section, it is selected three dependent variables denoted by ROA, ROE and Tobin's $Q$. The corporate governance variables such as firm size, board size, audit committee, leverage, and age are employed as explanatory variables. The specific model is given as below:

$$
\begin{aligned}
& F P=\alpha+\beta_{1} F S+\beta_{2} B S+\beta_{3} \text { Lev }+\beta_{4} \text { Age }+\beta_{5} A C+\varepsilon i \\
& \text { Where, } \\
& \text { FP = Firm performance ( ROA, ROE and Tobin's } Q \text { are the dependent variables) } \\
& \alpha=\text { Constant terms } \\
& \beta=\text { Coefficients }
\end{aligned}
$$

Corporate governance issues:

$$
\begin{aligned}
& \text { FS = Firm size (log of total assets) } \\
& \text { BS = Board size } \\
& \text { Lev = Leverage (total debt scaled by total assets) } \\
& \text { Age = Age of the sample firm } \\
& \text { AC = Audit committee } \\
& \varepsilon i=\text { Residual error }
\end{aligned}
$$

\section{Empirical Results}

\subsection{Descriptive statistics analysis}

Descriptive statistics summarizes the data as per the objectives of the study. Table 4.1 shows the distribution of the performance measurement ( return on assets, return on equity and Tobin's $Q$ and the firm specific variables ( board size, leverage, age of the firm, audit committee, and firm size). Board size ranges from 6 members to 11 members, leading the average member to 8 . The average size is quite reasonable as it is consistent with the result of Jensen and Ruback (1983). Likewise, leverage pattern ranges from 2 percent to 191 percent, leading to 60 percent on average. Age ranges from 10 to 49 years, leading to 25.26 years with the standard deviation of 10.87 years. Similarly, audit committee ranges 
from 0 to 3 and on an average sample firms have 2.67 members to investigate the financial performance. This figure is in compliance with the company act 2063. The mean statistics of the firm size as measured by log of assets is Rs 6.70 million ranged from Rs 3.99 to Rs 8.90 million. Return on assets ranges from negative 168.94 percent to 100 percent and on average return of sample firm is 7.34 percent. Similarly, return on equity ranges from negative 86.03 percent to 342.30 percent and average value of return is 50.74 percent. Finally, Tobin's $Q$ ranges from 0.19 times to 15.65 times and average is 2.17 times. The variation indicated by standard deviation is largest for return on equity 76.91 percent for dependent variable and lowest from 0.40 for the leverage, firm specific variable.

Table 4.1: Descriptive statistics for the selected variables

The table reports the descriptive statistics comprises minimum, maximum, mean and standard deviation of the sampled 18 firms from 2010 to 2015 for 6 years. Board size refers to the number board members, leverage refers to the total debt scaled by total assets, age refers to the age of the firm, audit committee refers to the number of independent directors include in this committee, firm size refers to the total assets as log of TA, ROA refers to the net income scaled by total assets, ROE refers to the net income scaled by total equity and Tobin's $Q$ is computed as total assets minus book equity plus market equity scaled by total assets.

\begin{tabular}{|l|c|c|c|c|c|}
\hline & N & Minimum & Maximum & Mean & SD \\
\hline Board size (number) & 108 & 6 & 11 & 8.15 & 1.55 \\
\hline Leverage (\%) & 108 & 2.00 & 191 & 60.00 & 40.00 \\
\hline Age (years) & 108 & 10.00 & 49.00 & 25.26 & 10.87 \\
\hline Audit Committee (numbers) & 108 & 0.00 & 3.00 & 2.67 & 0.95 \\
\hline ROA (\%) & 108 & -168.94 & 100.00 & 7.34 & 43.80 \\
\hline ROE (\%) & 108 & -86.03 & 342.30 & 50.74 & 76.91 \\
\hline Q ( Times) & 106 & 0.19 & 15.65 & 2.17 & 2.25 \\
\hline Lnsize (in million) & 108 & 3.99 & 8.90 & 6.70 & 1.24 \\
\hline
\end{tabular}

Sources: NEPSE data base/Annual report of respective firms.

\subsection{Correlation Analysis}

Correlation among corporate governance and firm performance is explained in this section and presented in table 4.2. The correlation coefficients reveal the degree of relationship between firm performance and variables affecting firm performance of the sample firms. The value of correlation coefficient ranges from +1 to -1 .

Table 4.2: Pearson Correlation matrix

The table shows bivariate Pearson's correlation coefficient for the dependent and explanatory variables employed in this study. The sample consists 108 firm years from the annual report of listed firms in NEPSE for the period of 2010 to 2015. The BS, Lev, Age, AC, ROA, ROE, Tobin's $Q$, and firm size are presented here as defined in table 4.1.

\begin{tabular}{|l|c|c|c|c|c|c|c|c|}
\hline & Board size & Leverage & Age & $\begin{array}{c}\text { Audit } \\
\text { Committee }\end{array}$ & ROA & ROE & Q & Lnsize \\
\hline Board size & 1 & & & & & & & \\
\hline Leverage & -0.479 & 1 & & & & & & \\
\hline
\end{tabular}




\begin{tabular}{|l|c|c|c|c|c|c|c|c|} 
Age & -0.034 & -0.112 & 1 & & & & \\
\hline $\begin{array}{l}\text { Audit } \\
\text { Committee }\end{array}$ & 0.263 & -0.208 & 0.074 & 1 & & & & \\
\hline ROA & 0.214 & -0.683 & 0.318 & 0.027 & 1 & & & \\
\hline ROE & -0.163 & 0.091 & 0.406 & 0.103 & 0.134 & 1 & & \\
\hline Q & 0.222 & -0.26 & -0.014 & 0.17 & 0.211 & 0.113 & 1 & \\
\hline Lnsize & 0.224 & -0.219 & -0.068 & 0.312 & -0.022 & -0.059 & -0.329 & 1 \\
\hline
\end{tabular}

Another important way of examining the explanatory variables is to test for potential multicollinearity which is tested by producing a correlation matrix (Brooks, 2002). Higher the linear relation, higher would be the chances of misinterpretation among independent variables. It is apparent that none of the variables have been observed high correlation, actually, more that 0.8 is considered as the problem of multicollinearity. The correlation coefficients are generally low except with some variables. The highest correlation has been observed to be -0.683 between return on assets and leverage. Thus all the variables included in this study can be incorporated into the further regression analysis.

\section{Regression Analysis}

The univariate and multivariate regression of the firm specific variables on firm performance have been analyzed in terms of return on assets, return on equity and Tobin's $Q$. The explanatory variables used in this study affect firm performances which are presented in table 4.3.

Table 4.3 reveals the result of regression of various models of corporate governance variables on return on assets. The first five models include one of the five explanatory variables at a time. Model 6, 7 and 8 include various combinations of explanatory variables and model 9 includes all of the independent variables simultaneously. Model 1, 2 and 3 provides significant relationship between firm performance and corporate governance variables. The age of the firms is positively statistically significant at 1 percent level of significance whereas board size and leverage are negatively significant.

Model 6 attempts to show the separate influence of board size and leverage on return on assets. The tstatistics suggests that the coefficients are estimated with high degree of precision. It results that both of them have significant impact on firm performance. Similarly, model 7 reveals that leverage and age of the firm have negative and positive relation. The t-statistics shows the coefficients are again high degree of precision. Including 3 variables together in model 8 , only the age has been found to be highly significant. Audit committee and size of the firm do not have significant role in firm performance.

In model 9, while all the variables are simultaneously included, only the t-statistics of leverage, age and firm size have been found to be significant. The results suggest that leverage, age and firm are more important than board size and audit committee in predicting firm performance.

Table 4.3 Estimated relationships between return on assets and firm specific variables 
The table is concerned with the data comprises the sample of non financial firms and presents regression result of various regression equation of explanatory variables on firm performance (ROA). The data are from NEPSE and annual report of respective firms and the sample contains 18 firms listed in NEPSE from 2010 to 2015. The $t$-values of each regression coefficients are provided to have the information regarding significance of the coefficients of the corporate governance variables selected in this study.

\begin{tabular}{|c|c|c|c|c|c|c|c|c|c|}
\hline Model & Intercept & $\mathrm{BS}$ & Lev & Age & $A C$ & Lnsize & $\mathrm{R}^{2}$ & F-value & Sig \\
\hline 1 & $\begin{array}{l}-41.835 \\
-1.884\end{array}$ & $\begin{array}{c}-6.035 \\
-2.254^{*}\end{array}$ & & & & & 0.046 & 5.079 & 0.026 \\
\hline 2 & $\begin{array}{c}52.447 \\
9.342\end{array}$ & & $\begin{array}{l}-75.053 \\
-9.627^{*}\end{array}$ & & & & 0.466 & 92.675 & 0.00 \\
\hline 3 & $\begin{array}{l}-25.056 \\
-2.457\end{array}$ & & & $\begin{array}{c}1.283 \\
3.455^{*}\end{array}$ & & & 0.101 & 11.94 & 0.00 \\
\hline 4 & $\begin{array}{l}4.038 \\
0.318\end{array}$ & & & & $\begin{array}{l}1.239 \\
0.276\end{array}$ & & 0.001 & 0.076 & 0.783 \\
\hline 5 & $\begin{array}{c}12.453 \\
0.535 \\
\end{array}$ & & & & & $\begin{array}{l}-0.763 \\
-0.223 \\
\end{array}$ & & 0.05 & 0.824 \\
\hline 6 & $\begin{array}{c}90.819 \\
4.199\end{array}$ & $\begin{array}{c}-4.14 \\
-1.835^{* *}\end{array}$ & $\begin{array}{l}-82.768 \\
-9.425^{*}\end{array}$ & & & & 0.483 & 49.058 & 0.00 \\
\hline 7 & $\begin{array}{c}25.706 \\
2.824\end{array}$ & & $\begin{array}{l}-72.044 \\
-9.693 *\end{array}$ & $\begin{array}{l}0.987 \\
3.62 *\end{array}$ & & & 0.526 & 58.183 & 0.00 \\
\hline 8 & $\begin{array}{l}-25.221 \\
-1.003\end{array}$ & & & $\begin{array}{c}1.281 \\
3.394 *\end{array}$ & $\begin{array}{l}0.169 \\
0.037\end{array}$ & $\begin{array}{l}-0.037 \\
-0.011\end{array}$ & 0.101 & 3.905 & 0.011 \\
\hline 9 & $\begin{array}{c}91.631 \\
3.415\end{array}$ & $\begin{array}{l}-2.358 \\
-1.089\end{array}$ & $\begin{array}{c}-81.52 \\
-9.727^{*}\end{array}$ & $\begin{array}{c}0.928 \\
3.445^{*}\end{array}$ & $\begin{array}{l}-3.891 \\
-1.186\end{array}$ & $\begin{array}{c}-4.351 \\
-1.751^{* * *}\end{array}$ & 0.562 & 26.222 & 0.00 \\
\hline
\end{tabular}

$t$-values are given in lower level, * $1 \%$ significant level, $* * 5 \%$ level of significance, ${ }^{* * *} 10 \%$ level of significance

The regression result of board size, leverage, age of the firm, audit committee and firm size on return on equity is presented in table 4.4. The first five models include one of the five explanatory variables at a time. Model 6 to 8 include various combinations of the explanatory variables and model 9 includes all the explanatory variables simultaneously. The results are as expected and encouraging and more or less similar to the hypothesis. The firm performance (ROE) is negatively influenced by board size, positively influenced by leverage and age of the firm but two other variables are not statistically significant. The board size and age of the firm individually have been found to be statistically significant.

Specially, model 6 attempts to explore the separate influence of board size and leverage on firm performance. The t-statistics suggest that board size is negatively significant at 10 percent level of significance.

Table 4.4 Estimated relationships between return on equity and firm specific variables

The table is concerned with the data comprises the sample of non financial firms and presents regression result of various regression equation of explanatory variables on firm performance (ROE). The data are 
from NEPSE and annual report of respective firms and the sample contains 18 firms listed in NEPSE from 2010 to 2015. The t-values of each regression coefficients are provided to have the information regarding significance of the coefficients of the corporate governance variables selected in this study.

\begin{tabular}{|c|c|c|c|c|c|c|c|c|c|}
\hline Model & Intercept & BS & Lev & Age & $A C$ & Lnsize & $\mathrm{R}^{2}$ & $\begin{array}{c}\mathrm{F}- \\
\text { value }\end{array}$ & Sig \\
\hline 1 & $\begin{array}{c}116.67 \\
2.962 \\
\end{array}$ & $\begin{array}{c}-8.093 \\
-1.704^{* *} \\
\end{array}$ & & & & & 0.027 & 2.903 & 0.091 \\
\hline 2 & $\begin{array}{c}40.225 \\
2.993 \\
\end{array}$ & & $\begin{array}{c}17.494 \\
0.937 \\
\end{array}$ & & & & 0.008 & 0.878 & 0.351 \\
\hline 3 & $\begin{array}{c}-21.916 \\
-1.27\end{array}$ & & & $\begin{array}{c}2.876 \\
4.578^{*}\end{array}$ & & & 0.165 & 20.96 & 0 \\
\hline 4 & $\begin{array}{c}28.538 \\
1.286 \\
\end{array}$ & & & & $\begin{array}{l}8.325 \\
1.016 \\
\end{array}$ & & 0.011 & 1.126 & 0.291 \\
\hline 5 & $\begin{array}{l}74.98 \\
1.836 \\
\end{array}$ & & & & & $\begin{array}{c}-3.62 \\
-0.604 \\
\end{array}$ & 0.003 & 0.365 & 0.547 \\
\hline 6 & $\begin{array}{c}111.66 \\
2.143 \\
\end{array}$ & $\begin{array}{c}-7.71 \\
-1.428 * * * \\
\end{array}$ & $\begin{array}{l}3.131 \\
0.148 \\
\end{array}$ & & & & 0.027 & 1.449 & 0.239 \\
\hline 7 & $\begin{array}{c}-36.741 \\
-1.467 \\
\end{array}$ & & $\begin{array}{r}2.838 \\
4.498 * \\
\end{array}$ & $\begin{array}{c}5.92 \\
0.818 \\
\end{array}$ & & & 0.17 & 10.82 & 0.00 \\
\hline 8 & $\begin{array}{l}-14.97 \\
-0.354 \\
\end{array}$ & & & $\begin{array}{c}2.799 \\
4.403 *\end{array}$ & $\begin{array}{l}7.477 \\
0.977 \\
\end{array}$ & $\begin{array}{l}-3.722 \\
-0.639\end{array}$ & 0.174 & 7.283 & 0.00 \\
\hline 9 & $\begin{array}{l}2.699 \\
0.043\end{array}$ & $\begin{array}{c}-6.686 \\
-1.467^{*}\end{array}$ & $\begin{array}{c}18.156 \\
0.917\end{array}$ & $\begin{array}{l}2.837 \\
4.46^{*}\end{array}$ & $\begin{array}{l}10.957 \\
1.454^{*}\end{array}$ & $\begin{array}{l}-1.383 \\
-0.236\end{array}$ & 0.209 & 5.374 & 0.00 \\
\hline
\end{tabular}

$t$-values are given in lower level, * $1 \%$ significant level, $* * 5 \%$ level of significance, ${ }^{* * *} 10 \%$ level of significance

Model 7 (table 4.3) board size is replaced by age, leverage is dominant. In model 8 age, audit committee and firm size are included, age is statistically significant means that higher the age, the larger the return on equity. In model 9, when all the explanatory variables are simultaneously included, the t-statistics of board size, age of the firm and audit committee have been found to be statistically significant. The result suggests that board sizes, age of the firm and audit committee are more important in predicting firm performance than other variables.

The table 4.5 reveals that beta coefficients of board size, audit committee are positive which indicate that higher the board size and audit committee higher would be the Tobin's $Q$. The coefficients of Leverage, age and firm size are negative which indicate that higher the leverage, age and firm size have lower Tobin's Q.

Table 4.5 Estimated relationships between Tobin's $Q$ and firm specific variables 
The table is concerned with the data comprises the sample of non financial firms and presents regression result of various regression equation of explanatory variables on firm performance (Tobin's Q). The data are from NEPSE and annual report of respective firms and the sample contains 18 firms listed in NEPSE from 2010 to 2015. The $t$-values of each regression coefficients are provided to have the information regarding significance of the coefficients of the corporate governance variables selected in this study.

\begin{tabular}{|c|c|c|c|c|c|c|c|c|c|}
\hline Model & Intercept & BS & Lev & Age & $A C$ & Lnsize & $\mathrm{R}^{2}$ & F-value & Sig \\
\hline 1 & $\begin{array}{l}-0.432 \\
-0.379\end{array}$ & $\begin{array}{c}0.319 \\
2.32 * *\end{array}$ & & & & & 0.049 & 5.384 & 0.022 \\
\hline 2 & $\begin{array}{l}3.081 \\
7.823 \\
\end{array}$ & & $\begin{array}{c}-1.488 \\
-2.745^{*}\end{array}$ & & & & 0.068 & 7.536 & 0.007 \\
\hline 3 & $\begin{array}{l}2.244 \\
4.015 \\
\end{array}$ & & & $\begin{array}{l}-0.003 \\
-0.142 \\
\end{array}$ & & & 0.04 & 0.008 & 0.567 \\
\hline 4 & $\begin{array}{l}1.101 \\
1.709 \\
\end{array}$ & & & & $\begin{array}{c}0.402 \\
1.763^{* * *} \\
\end{array}$ & & 0.029 & 3.106 & 0.081 \\
\hline 5 & $\begin{array}{l}6.233 \\
5.369 \\
\end{array}$ & & & & & $\begin{array}{c}-0.609 \\
-3.554^{*}\end{array}$ & 0.108 & 12.628 & 0.001 \\
\hline 6 & $\begin{array}{l}1.412 \\
0.933 \\
\end{array}$ & $\begin{array}{l}0.179 \\
1.143 \\
\end{array}$ & $\begin{array}{c}-1.139 \\
-1.832 * * *\end{array}$ & & & & 0.079 & 4.432 & 0.014 \\
\hline 7 & $\begin{array}{l}3.362 \\
4.983 \\
\end{array}$ & & $\begin{array}{c}-1.525 \\
-2.779 *\end{array}$ & $\begin{array}{c}-0.01 \\
-0.513 \\
\end{array}$ & & & 0.07 & 3.873 & 0.024 \\
\hline 8 & $\begin{array}{c}5.81 \\
4.678 \\
\end{array}$ & & & $\begin{array}{c}-0.012 \\
-0.66 \\
\end{array}$ & $\begin{array}{c}0.725 \\
3.268^{*}\end{array}$ & $\begin{array}{c}-0.79 \\
-4.533^{*}\end{array}$ & 0.194 & 8.164 & 0.00 \\
\hline 9 & $\begin{array}{l}6.074 \\
3.459\end{array}$ & $\begin{array}{c}0.223 \\
1.554^{* * *}\end{array}$ & $\begin{array}{c}-1.335 \\
-2.374^{* *}\end{array}$ & $\begin{array}{l}-0.017 \\
-0.956\end{array}$ & $\begin{array}{c}0.564 \\
2.629 *\end{array}$ & $\begin{array}{c}-0.897 \\
-5.397^{*}\end{array}$ & 0.296 & 8.424 & 0.00 \\
\hline
\end{tabular}

$t$-values are given in lower level, * $1 \%$ significant level, $* * 5 \%$ level of significance, ${ }^{* * *} 10 \%$ level of significance

However, the beta coefficients are significant for board size, leverage, audit committee and firm size. It reveals that four out of five variables have been found to be significant. It indicates those board size and audit committees have positive impact whereas leverage and firm size have negative impact on firm performance. It can be concluded that larger the board size and audit committee, better the firm performance.

\section{Conclusion}

The study was conducted on corporate governance and firm performance of Nepalese non financial firms listed in Nepal stock exchange from 2010 to 2015 based on pooled cross sectional data of 18 non financial firms. The study focused on four specific areas of the Nepalese economy: manufacturing and processing, trading, hotels, and hydro sectors. The study examined, if return on assets, return on equity, and Tobin's $Q$ are associated with board size, leverage, age, audit committee and firm size. The overall results of this study can be summarized as follows: 
The result reveals that board size, leverage, and age of the firm have significant impact on return on assets. Board size and leverage have negative impact whereas age of the firm has positive impact. While going through three variables, age of the firm has been found to be more informative than board size and leverage of the firm.

Return on equity is positively influenced by size, age and audit committee and negatively influenced by board size. Age and audit committee have been found to be statistically strong in determining firm performance (ROE).

Similarly, Tobin's $Q$ (Total assets plus market equity minus book equity scaled by total assets) is influenced by board size, leverage, audit committee and firm size. Board size and audit committee are positively and leverage and firm size are negatively associated with Tobin's $Q$. The result concludes that larger the board size and audit committee, the higher the firm performance.

\section{Limitations and direction for future research}

There are several firm performance measures such as earnings per share, debt equity ratio, market price per share which is not included in this study. In fact that this study focuses on return on assets, return on equity and Tobin's $Q$. In addition, the study employs internal factors but external factors such as business environment, ethical behavior, rules and regulation of the country and social responsibility could have significant impact on firm performance. The study includes only 18 non financial firms derived from manufacturing and processing, hotels, hydro and trading. It could have been better, if other sectors with large samples covering in such type of study. One could also conduct a comparative study of corporate governance variables on firm performance of financial and non financial firms in Nepal for further insights. Further suggestion to financial executive is, Nepalese firms should pay due attention to board size, leverage and age of the firm while they are planning to increase their firm performance as these variables have been found to be statistically significant.

\section{REFERENCES}

Awan, S.H. (2012). Effect on Board Composition on Firm Performance: A Case of Pakistan Listed Companies. Interdisciplinary Journal of Research in Business, 3 (10).

Bebchuk, L. (2006). Letting Shareholders Set the Rules. Harvard Law Review, 119, 1784-1813

Bebchuk, L., Cohen, A. and Farrell, A. (2009). What Matters in Corporate Governance? The Review of Financial Studies, 22, 783-827.

Bebchuk, L., Cohen, A., and Wang, C. (2013). Learning and Disappearing Association between Governance and Returns. Journal of Financial Economics, 108, 323-348. 
Berger, A.N. and Udell, G.F. (1998). The Economics of Small Business Finance: The Roles of Private Equity and Debt Markets in Financial Growth Cycle. Journal of Bank Finance, 22, 613-673.

Brown, L.D. and Caylor, M.L. (2006). Corporate Governance and Firm Performance. Journal of Accounting and Public Policy, 25(4), 409-434.

Boone, A.L., Casares, F., L., Karpoff, J.M., and Raheja, C.G. ( 2007). The determinants of corporate board size and composition: An Empirical Analysis. Journal of Financial Economics, 85(1), 66-101.

Borghesi, R., Houston, J., and Naranjo, A. (2007). Value, Survival and the Evolution of Firm Organizational Structure. Financial Management, 36(3), 5-31.

Bocean, C.G., Barbu, C.M. (2007). Corporate Governance and Firm Performance. Management and Marketing Journal, 5(1), 125-131.

Claessens, S., Djankov, S., Fan, J. P., and Lang L.H. (2002). Disentangling the Incentive and Entrenchment Effects of Large Shareholdings. The Journal of Finance, 57(6), 2741-2771.

Coles, J.L., Daniel, N. and Naveen, L. (2008). Boards: Does one size fit all? Journal of Financial Economics, 82(7), 329-356.

Company act (2006). Company Announcement, retrieved from www.sharesansar.com on September 22, 2016.

Dalton, D., R. (1999). Number of Directors and financial performance: A Meta Analysis, The Academy of Management Journal, 42(6), 674-682.

Evans, D.S. (1987). The Relationship between firm growth, size and age: Estimates for 100 Manufacturing Industries. The Journal of Industrial Economics, 567-581.

Fallatah, Y., and Dickins, D. (2012). Corporate governance and firm performance and value in Saudi Arabia. African Journal of Business Management, 6(36), 10025-10034.

Fama, E. F. and Jensen, M. C. (1983). Separation of ownership and control, Journal of Law and Economics, 26, 3011-325.

Goldman, A. and Barlev, B. (1974). The Auditor-Firm conflict of interests: its implications for independence. The Accounting Review, 707-718.

Gompers, P. A., Ishii, J. L., \& Metrick (2003). A. Corporate governance and equity prices. Quarterly Journal of Economics, 118 (1), 107-155. 
Hillman, A.J. and Dalziell,T. ( 2003). Boards of Directors and firm Performance: Integrating Agency and resource dependency perspectives. Academy of Management Review, 28: 383-396.

Jensen, M.C. (1993). The Modern Industrial Revolution, Exit, and the Failure of Internal Control Systems, Journal of Finance, 48(3), 831-880.

Jensen, M.C. and Meckling, W.H. (1976). Theory of firm: Managerial Behavior, Agency costs and Ownership Structure. Journal of financial Economics, vol. 3, pp. 305-360.

Jensen, M.C. and Ruback, R.S. (1983). The Market for Corporate Control: The Scientific Evidence. Journal of Financial Economics, 11, 5-30.

Klein, A. (1998). Firm Performance and Board Committee Structure. Journal of Law and Economics, 41(1), 275-303.

La Porta, R., Lopez de Silanes, F., Shleifer, A., and Vishny, R. (2000). Investor Protection and Corporate Valuation. Journal of Financial Economics, 58, 3-27.

Larcker, D. F., Richardson, S. A., \& Tuna, I. (2007). Corporate Governance, Accounting Outcomes, and Organizational Performance. The Accounting Review, 82(4), 963-1008.

Lipczinsky, J. and Wilson, J. (2001) Industrial Organization, Edinburg Gate: Prentice Hall.

Lipton, M. and Lorsch, J., W. (1992). A Modest Proposal for improved corporate governance, Business Lawer, 48(1), 59-77.

Majumdar, S.K. and Chhibber, P. (1999). Capital structure and performance: Evidence from a transition economy on an aspect of corporate governance. Public Choice, 98(3-4), 287-305.

Mamatzakis, E. and Bermpei, T. (2015). The Effect of Corporate Governance on the Performance of US Investment Banks, Journal of Finance, 24(2), 191 -239.

Nicholsan, G.J. and Kiel, G.C. (2007). Can Directors Impact Performance? A Case - based test of three theories or corporate governance. An International Review, 15(4), 585-608.

NRB (2009). Banking and Financial Statistics, Nepal Rastra Bank.

NRB (2010). Banking and Financial Statistics, Nepal Rastra Bank

Organization for Economic Cooperation and Development (OECD). 2004. Principles of Corporate Governance: OECD.

Rahman, R.A. and Haniffa, R.M. (2006). The effect of role duality on corporate performance in Maslaysia. Corporate ownership and control, 2(2), 40-47. 
Rajgopalan, N., and Zhang, Y. (2009). Recurring Failures in corporate governance: A global disease? Business Horizon, 52 (6), 545.

Ramzan, M.Y. (2013). A view about the Determinants of change in share prices: A case from Karanchi stock exchanges. Interdisciplinary Journal of Contemporary Research in Business, 4(2), 41-57.

Shleifer, A. and Vishny, R. (1997). Survey of Corporate governance. Journal of Finance, 52(2), 240-265.

Weill, L. (2003). Leverage and Corporate performance: A Frontier Efficiency Analysis on European Countries. EFWA Working Paper.

\section{Appendix 1}

List of selected sample firms for the study including years of firm performance and number of observations.

\begin{tabular}{|c|l|l|c|}
\hline S.N. & Name of sample firms & Years & Observation \\
\hline 1 & Soaltee Hotel Limited (SHL) & $2010,11,12,13,14,15$ & 6 \\
\hline 2 & Nepal Bitumin and Barrel(NBB) & $2010,11,12,13,14,15$ & 6 \\
\hline 3 & Nepal Lube Oil (NLO) & $2010,11,12,13,14,15$ & 6 \\
\hline 4 & Unilever Nepal Limited (UNL) & $2010,11,12,13,14,15$ & 6 \\
\hline 5 & Grakhkali Rubber Udhyog(GRU) & $2010,11,12,13,14,15$ & 6 \\
\hline 6 & Himalayan Distillery Limited (HDL) & $2010,11,12,13,14,15$ & 6 \\
\hline 7 & Arun Hydro Power Limited (AHP) & $2010,11,12,13,14,15$ & 6 \\
\hline 8 & Butwal Hydro Power (BHP) & $2010,11,12,13,14,15$ & 6 \\
\hline 9 & Chilime Hydro Power (CHP) & $2010,11,12,13,14,15$ & 6 \\
\hline 10 & Salt Trading Corporation(STC) & $2010,11,12,13,14,15$ & 6 \\
\hline 11 & Shree Ram Sugar Mill (SRS) & $2010,11,12,13,14,15$ & 6 \\
\hline 12 & National Hydro Power (NHP) & $2010,11,12,13,14,15$ & 6 \\
\hline 13 & Bottlers Balaju Nepal (BBN) & $2010,11,12,13,14,15$ & 6 \\
\hline 14 & Bottlers Terai Nepal (BTN) & $2010,11,12,13,14,15$ & 6 \\
\hline 15 & Oriental Hotels Limited (OHL) & $2010,11,12,13,14,15$ & 6 \\
\hline 16 & Bishal Bazaar Company (BBC) & $2010,11,12,13,14,15$ & 6 \\
\hline 17 & Nepal Khadya Udhyog (NKU) & $2010,11,12,13,14,15$ & 6 \\
\hline 18 & Tara Gaon Regency Hotel (TGH) & $2010,11,12,13,14,15$ & 108 \\
\hline & \multicolumn{2}{|c|}{ Total observations } & \\
\hline
\end{tabular}

Note: S.N. indicates serial number for the sample firms selected for the study.

Source: Annual reports of the listed firms for the fiscal year mid July 2010 to mid July 2015 and Nepal Stock Exchange data base. 